Article

\title{
An Analysis of the Entrepreneurial University in the Faculties of Education in Spain: Self-perception among Deans
}

\author{
Jessica Paños-Castro ${ }^{1 *}$, Leire Markuerkiaga ${ }^{2}$ and María José Bezanilla ${ }^{3}$ \\ 1 University of Deusto; jessicapanos@deusto.es \\ 2 Mondragon University; lmarkuerkiaga@mondragon.edu \\ 3 Univeristy of Deusto; marijose.bezanilla@deusto.es \\ * Correspondence: jessicapanos@deusto.es; Tel.: 944139003
}

\begin{abstract}
Universities have increasingly incorporated a third mission into their strategic planning. In addition to teaching and research, they have emphasised the training of entrepreneurs. However, there is still a lot of work to be done, as this process is facing resistance. The Entrepreneurial University covers all disciplines, including faculties of education. However, it has been shown that entrepreneurship tends to be more related to the faculties of economics and engineering, with a lesser presence in the faculties of education for various reasons: they consider entrepreneurship to be alien to their teaching role, there is a lack of entrepreneurial culture, and the objective of the Entrepreneurial University is unknown. The aim of this study is to analyse the level of entrepreneurship in Spanish faculties and schools of education. Forty deans and heads of education faculties in Spain took part in the survey. The results indicated a sufficient level of entrepreneurship; the dimensions related to active methodologies, and mission and strategy were the most developed, whereas entrepreneurship funding and entrepreneurship training for faculty employees were the least developed areas. Some deans noted that entrepreneurship was alien to their professional performance, although courses and good practices for the development of entrepreneurial initiative are gradually being implemented.
\end{abstract}

Keywords: entrepreneurial university; entrepreneurship; faculties of education; self-perception; triple helix; third mission; teacher training.

\section{Introduction}

The need for and importance of entrepreneurship in today's Knowledge Society is undeniable as a key competence for personal development, social inclusion, active citizenship and employment [1]. Universities have an important role to play in raising awareness and developing and promoting entrepreneurship, both among students and among teaching and research staff $[2,3]$. Ultimately, higher education institutions are proactive subjects in regional development, economic growth, technology transfer, innovation promotion, and social development [4]. Until recently there has had been a lack of coordination between the spheres of industry and academia; universities have even been considered non-entrepreneurial institutions due to their hierarchical structure, lack of entrepreneurial talent, the need for immediate results and the excessive conservatism of the corporate culture, among others [5]. Etzkowitz et al. [6] pointed out that the concept of the Entrepreneurial University in many countries is causing an invisible revolution due to some exogenous (environmental factors that are difficult to control) and endogenous (system factors that are easier to control) factors. These are related to internal transformations within universities such as organisational changes, funding cuts, bottom-up structures, and economic and political crises, among others.

The mission of the Entrepreneurial University focuses on the tripartite cooperation between teaching, research, and entrepreneurship [4]. The Entrepreneurial University is also known as the third mission or triple helix model, since a third role is added to those of teaching and research. This role involves economic and social development, which 
should occur without the need to weaken teaching and research [7]. In other words, the University-Government-Industry triple helix model should establish synergies with the others. Universities produce knowledge and technologies for industrial application; government acts as a public entrepreneur; and industry provides capital, management skills and a network of relationships [8]. According to Corti and Riviezzo [9], in the near future there will be universities with incubators adjacent to classrooms and laboratories. However, it is undeniable that the three missions have not been given the same weight in all universities [10, 6, 11].

The response to entrepreneurship is different in each university and is determined by contextual factors, including whether the university is public or private, its organisational culture, the country's government policies, and the need to seek funding [12]. The literature indicates that the Entrepreneurial University has not developed to the same extent across universities, whether they are public or private. This depends on each university's ecosystem, background and tradition, size, and entrepreneurial culture [13]. Brătucu et al. [14] argued that the entrepreneurial university is not homogeneous in all countries, as differences exist between European universities, which advocate the teaching mission, and American universities, which tend to favour research. As Pinheiro and Stensaker [15] and Salati, Brandão, Leite and Rücker [16] stated, universities in Europe have traditionally been seen to react poorly to demand. Following Martínez, García and Duarte [17], public universities have a higher number of lecturers and professors focused on research than private universities, and therefore have greater availability for entrepreneurial actions. According to Martínez, García and Duarte [17], teaching staff in public universities are more oriented towards academic careers and scholarly outputs. Private universities, in contrast, show higher levels of interaction with the market environment and have stronger infrastructures to support entrepreneurship. However, in general terms, universities do not usually fulfil the third mission due to the requirements related to research production output indicators for measuring their teaching performance (number of papers and book chapters published, and seminars attended). Consequently, there is low cooperation and articulation between higher education institutions and businesses [18].

García-Aracil et al. [19] and Etzkowitz and Zhou [20] noted that the Entrepreneurial University is a contradiction in terms. In other words, an Entrepreneurial University can mean three things. Firstly, that the university itself, as an organisation, is entrepreneurial. Secondly, that members of the university (academic and non-academic staff and students) become entrepreneurs in some way. And thirdly, that the interaction of the university with the environment (region) follows entrepreneurial patterns [19].

\section{Entrepreneurship in Faculties of Education and its importance}

The Entrepreneurial University encompasses all disciplines, areas, and spheres of the institution [21,5]. In practice, any university has the potential to help industrial development, regardless of its level and mission [20]. However, entrepreneurship is sometimes associated with economics and engineering faculties [22, 23, 20,24] and less with the humanities, as academics in these disciplines tend to consider entrepreneurship to be alien to them [25]. One of the studies carried out by Sam and van der Sijde [7] found that the arts and social sciences disciplines do not have a strong predisposition towards engaging in entrepreneurship mainly due to a lack of entrepreneurial role models within the university, a lack of an entrepreneurial culture, and a shortage of academic promotion incentives. Furthermore, the participants in the study said that they did not know what the term Entrepreneurial University refers to [7]. As Orozco, Aristizabal and Villaveces [26] pointed out, not all teaching staff are convinced that engaging in entrepreneurship is valuable for their performance and that of their students. Furthermore, lecturers and professors in social science disciplines tend to be the most reluctant [26].

Traditionally, participants in entrepreneurship programmes have generally been students from business disciplines; while programmes are often interdisciplinary, faculty and student participation from the arts and sciences has tended to be minimal [21]. 
Research carried out by Hannon [27] highlighted that business schools and faculties are the main areas offering entrepreneurial activities within the curriculum $(63.5 \%)$, and to a much lesser extent, engineering faculties (8.81\%) and art and design faculties (8.47\%). University curricula do not include sufficient entrepreneurship education, courses and programmes [28, 29]. Although the European Commission [31] invited Member States to ensure that entrepreneurship competences would be integrated into curricula at all levels of education by the end of 2015, there is little provision of entrepreneurship programmes in formal education [31].

Creating an Entrepreneurial University requires many years of cultural changes in organisations [7] and infrastructures; the implementation of flexible innovation policies [14]; the incorporation of entrepreneurship into the curricula of the different university degrees with the aim of promoting entrepreneurship among students and academics [12]; and joint work between faculties, departments and other structures to create synergies and links, and break down boundaries and traditional silos [32].

Marzocchi, Kitagawa and Sánchez-Barrioluengo [33] argued that it is vital to have entrepreneurial teaching staff in all disciplines, as they become role models and play an important part in students' teaching-learning process. To this end, initial teacher training is essential: 'Every student, teacher and existing teacher should benefit from at least one experience of training on the key topics and methods related to entrepreneurial learning and entrepreneurship education during their career' [34] (p. 7). Along similar lines, the Council of the European Union [34] included increasing creativity, innovation and entrepreneurship at all levels of education and training among its strategic objectives.

The salience of entrepreneurship is such that the Spanish Government [36] has engaged in a commitment to promote an entrepreneurial nation with measures and goals to be achieved by 2030 . The 50 measures adopted by the Spanish government notably include number 44, 'University and Entrepreneurship': 'Spanish universities (both public and private) must play a key role in helping people learn entrepreneurial skills and promoting entrepreneurship' (p.123). The Spanish Government [36] recommends promoting a compulsory university subject on entrepreneurship in all undergraduate degrees to support students acquire entrepreneurial skills such as leadership, creativity and marketing; creating entrepreneurship centres; promoting an entrepreneurial culture within universities; creating university spin-offs; and the use of active methodologies such as learning by doing and through practice, among others. Along the same lines, Paños-Castro [37] argues that the development of entrepreneurial competence requires active and participatory methodologies so that students can experience first-hand the skills needed to be entrepreneurs.

Unfortunately, universities during the Covid-19 pandemic have faced major challenges in developing the third mission such as fewer financial funds, fewer internationally mobile students and employing more traditional methodologies [38]. However, they have also had opportunities such as employing educational innovation, employing new teaching-learning methodologies [39] and offer solutions through new relationship models with the productive fabric [40].

\section{Method}

\subsection{Objectives and Hypotheses}

The general objective of this research is to analyse the level of entrepreneurship in the different faculties and schools of education in Spain in order to assess their level before and after Covid, with a view to proposing future improvement actions.

There were two specific objectives: to examine whether there are significant differences by Autonomous Region and type of university (public or private), and to analyse the level of entrepreneurship before and after the Covid-19 pandemic.

This study examines the following research hypotheses: 
H1: Entrepreneurship levels in Spanish faculties and schools of education are low.

$\mathrm{H} 2$ : There are significant differences in entrepreneurship levels across the various Autonomous Regions.

H3: There are significant differences in levels of entrepreneurship based on the type of faculty/school (public/private).

H4: The 'active methodologies' dimension obtains the highest average when considering the type of education faculty.

H5: When a university has a faculty of economics, the level of entrepreneurship in the faculties and schools of education is higher.

H6: Covid-19 has not had a significant impact on the Entrepreneurial University dimensions of the faculties of education.

\subsection{Instrument}

Although the emerging literature on the Entrepreneurial University model has highlighted several of the new characteristics that universities should have, there has so far been little empirical work on these characteristics, the regional variations that can be expected, and the impact of these changes on university performance [41]. Several frameworks, models and tools are available for evaluating the Entrepreneurial University, including as EC-OECD, HEInnovate or MultiU-rank, among others [42], but these are directed at the university level and not at the faculty level.

This study has used the model and instrument for measuring the evaluation of the Entrepreneurial University that was initially validated by Markuerkiaga, Igartua and Errasti [43]. It was subsequently adapted for all the faculties and again validated by Errasti, Bezanilla, García-Olalla, Auzmendi and Paños [44]. Given that the language used in the model was highly technical to be used in the educational field, both the language and any other aspects considered relevant by experts in educational research were adapted as necessary. For this purpose, a trial was set up with 6 expert methodologists and sociologists of education with more than 20 years of experience. Two rounds were held until consensus was reached. In the first round the experts made their contributions independently; in the second round they were provided with a summary for them to make any changes they deemed fit. These experts noted the following points: levels should be removed and only the ends of a 0 to 10 point Likert scale should be included for the descriptors; the term teaching-learning should be used instead of only teaching; staff on restricted contracts should also be considered, in addition to associate professors for dimension 5; and 'university' should be replaced by 'faculty'. The resulting version of the model consisted of 14 dimensions, with a total of 44 items on a scale of 0 to 10. It was mandatory to answer all questions. In addition, participants could add qualitative comments for each dimension (see Table 1). 
Table 1. Dimensions and variables in the questionnaire.

\begin{tabular}{|c|c|}
\hline Dimensions & Variables \\
\hline \multirow[t]{2}{*}{ Legal and administrative context } & Legislation \\
\hline & Financing \\
\hline \multirow[t]{4}{*}{ Organisational context } & Financing \\
\hline & Technology \\
\hline & Technological maturity \\
\hline & R \& D budget \\
\hline \multirow[t]{2}{*}{ Entrepreneurship funding } & Funding for entrepreneurship teaching/learning \\
\hline & Funding for research into entrepreneurship \\
\hline \multirow{2}{*}{ Training in entrepreneurship for Faculty staff } & Knowledge transfer \\
\hline & Creation of university spin-outs \\
\hline \multirow{3}{*}{$\begin{array}{c}\text { Inclusion of professionals from businesses and organisations in } \\
\text { the development and delivery of the curriculum }\end{array}$} & Participation in the main governing body of the faculty \\
\hline & Participation in development and delivery \\
\hline & Professionals occasionally invited as guest speakers \\
\hline \multirow[t]{3}{*}{ Mission and strategy } & Presence in the mission \\
\hline & Objectives related to knowledge transfer \\
\hline & Objectives related to the development of social commit- \\
\hline \multirow[t]{3}{*}{ Support from the management team } & Support for entrepreneurship \\
\hline & Revenue for entrepreneurship \\
\hline & Presence on the agenda \\
\hline \multirow[t]{4}{*}{ Organisational design } & Link between teaching and research \\
\hline & Decentralised decision-making \\
\hline & Bottom-up structure \\
\hline & Financial autonomy \\
\hline \multirow[t]{3}{*}{ Training and research in entrepreneurship } & Entrepreneurial skills in the curriculum \\
\hline & Specific programmes on entrepreneurship \\
\hline & Research \\
\hline \multirow[t]{4}{*}{ Extracurricular training in entrepreneurship } & Entrepreneurship awareness \\
\hline & Identification of opportunities \\
\hline & Business plan development \\
\hline & Launch of spin-outs \\
\hline Active methodologies & Use of active methodologies \\
\hline
\end{tabular}


Placements with entrepreneurs

Design and development of innovative educational re-

sources

Internationalisation

$$
\begin{gathered}
\text { Joint degrees } \\
\text { Research } \\
\text { Revenue } \\
\text { Mobility }
\end{gathered}
$$

Other data relating to the faculty and/or university

\author{
Office for the Transfer of Research Results \\ Entrepreneurship Centre \\ Incubator \\ University-affiliated Technology Park \\ Courses and workshops \\ Training provision
}

Regarding the validity of the questionnaire, Fleiss's Kappa [45] was used to indicate the degree of agreement between three or more raters to assess inter-rater reliability, and showed that there was a good level of agreement (0.63). The Cronbach's Alpha coefficient for measuring internal consistency indicated that reliability was high (0.95). Furthermore, there were no negative corrected item-total correlations, and when removing the item, Cronbach's alpha had little to no increase (only 0.01).

\title{
3.3. Participants and procedure
}

Once the model had been adapted, the next step was to obtain the approval of the Research Ethics Committee of the University of Deusto to evidence that the study complies with Organic Law 15/1999, of December 13, on the Protection of Personal Data [46]. A pilot survey was then undertaken with three researchers to test that the online questionnaire was clearly understood, without ambiguity, and working well. After confirming that it was well, finally, the questionnaire was sent through the Qualtrics platform in two different periods. Firstly, from March 2020 to May 2020 (the data requested were related to the academic year prior to Covid-19, that is, 2018-2019); and secondly, from January 2021 to March 2021 (data corresponded to the academic year when the Covid-19 pandemic started, that is, 2019-2020). In both cases three reminders were provided, two via the Qualtrics platform and one by telephone.

The questionnaire was addressed to deans and directors of faculties and schools of education in Spain, as they had an overview of the faculty as a whole. The sample was obtained by first accessing the Registry of Universities, Institutions and Degrees of the Spanish Ministry of Education (known by its initials in Spanish as the RUCT) [47], which lists all universities and official academic degrees in Spain.

A total of 19 deans of faculties of education participated in the first period, whereas a total of 40 (the 19 from the first period and 21 new participants) took part during the second period. As shown in Table 1, 57.5\% of public universities and $42.5 \%$ of private universities in Spain participated in the survey. By Autonomous Region, 100\% of universities participated in Cantabria and Asturias, and there was high participation in Catalonia and Andalusia (see Table 2 and 3). 
Table 2. Research population and sample pre Covid.

\begin{tabular}{|c|c|c|c|c|c|}
\hline & & & $\begin{array}{l}\text { Popula- } \\
\text { tion }\end{array}$ & $\begin{array}{c}\text { Absolute frequency of partici- } \\
\text { pation }\end{array}$ & $\begin{array}{c}\text { Relative frequency of partici- } \\
\text { pation }\end{array}$ \\
\hline \multirow{3}{*}{ Type } & & Public & 50 & 11 & $22 \%$ \\
\hline & & Private & 38 & 8 & $21.05 \%$ \\
\hline & & TOTAL & 88 & 19 & $21.59 \%$ \\
\hline \multirow{18}{*}{$\begin{array}{l}\text { Autonomous } \\
\text { gion }\end{array}$} & \multirow{18}{*}{$\operatorname{Re}-$} & Basque Country & 6 & 1 & $16.6 \%$ \\
\hline & & Madrid & 13 & 3 & $23.07 \%$ \\
\hline & & Catalonia & 9 & 2 & $22.22 \%$ \\
\hline & & Valencia & 6 & 1 & $16.6 \%$ \\
\hline & & Murcia & 2 & 0 & $0 \%$ \\
\hline & & Castille and Leon & 10 & 2 & $20 \%$ \\
\hline & & Galicia & 6 & 0 & $0 \%$ \\
\hline & & Andalusia & 17 & 7 & $41.17 \%$ \\
\hline & & Cantabria & 2 & 0 & $0 \%$ \\
\hline & & Castille and La Mancha & 3 & 0 & $0 \%$ \\
\hline & & Extremadura & 3 & 0 & $0 \%$ \\
\hline & & Canary Islands & 4 & 1 & $25 \%$ \\
\hline & & La Rioja & 2 & 1 & $50 \%$ \\
\hline & & Navarre & 2 & 1 & $50 \%$ \\
\hline & & Asturias & 1 & 0 & $0 \%$ \\
\hline & & Aragon & 3 & 0 & $0 \%$ \\
\hline & & Balearic Islands & 1 & 0 & $0 \%$ \\
\hline & & TOTAL & 88 & 19 & $21.59 \%$ \\
\hline
\end{tabular}


Table 3. Research population and sample post Covid.

\begin{tabular}{|c|c|c|c|c|c|}
\hline & & & $\begin{array}{l}\text { Popula- } \\
\text { tion }\end{array}$ & $\begin{array}{c}\text { Absolute frequency of partici- } \\
\text { pation }\end{array}$ & $\begin{array}{c}\text { Relative frequency of partici- } \\
\text { pation }\end{array}$ \\
\hline \multirow{3}{*}{ Type } & & Public & 50 & 23 & $46 \%$ \\
\hline & & Private & 38 & 17 & $44.73 \%$ \\
\hline & & TOTAL & 88 & 40 & $45.45 \%$ \\
\hline \multirow{18}{*}{$\begin{array}{l}\text { Autonomous } \\
\text { gion }\end{array}$} & \multirow{18}{*}{ Re- } & Basque Country & 6 & 2 & $33.33 \%$ \\
\hline & & Madrid & 13 & 6 & $46.15 \%$ \\
\hline & & Catalonia & 9 & 6 & $66.66 \%$ \\
\hline & & Valencia & 6 & 3 & $50 \%$ \\
\hline & & Murcia & 2 & 0 & $0 \%$ \\
\hline & & Castille and Leon & 10 & 5 & $50 \%$ \\
\hline & & Galicia & 6 & 1 & $16.6 \%$ \\
\hline & & Andalusia & 17 & 10 & $58.82 \%$ \\
\hline & & Cantabria & 2 & 2 & $100 \%$ \\
\hline & & Castille and La Mancha & 3 & 0 & $0 \%$ \\
\hline & & Extremadura & 3 & 1 & $33.33 \%$ \\
\hline & & Canary Islands & 4 & 1 & $25 \%$ \\
\hline & & La Rioja & 2 & 1 & $50 \%$ \\
\hline & & Navarre & 2 & 1 & $50 \%$ \\
\hline & & Asturias & 1 & 1 & $100 \%$ \\
\hline & & Aragon & 3 & 0 & $0 \%$ \\
\hline & & Balearic Islands & 1 & 0 & $0 \%$ \\
\hline & & TOTAL & 88 & 40 & $45.45 \%$ \\
\hline
\end{tabular}

\section{Results}

The statistical package SPSS (version 27) was used for the data analysis. An analysis of the descriptive and non-experimental data is presented below to answer the hypotheses of section 3.1.

As shown in Table 4, the first hypothesis, namely, that the level of entrepreneurship in Spanish faculties and schools of education was low (taking into account Errasti, Bezanilla, García-Olalla, Auzmendi and Paños's scoring scale [44]) obtained an overall average of 5.4 when considering all the different aspects analysed. It was therefore rejected.

Table 4. Descriptive statistics of the level of entrepreneurship of faculties and schools of education in Spain

\begin{tabular}{cccccc}
\hline & N & Minimum & Maximum & Mean & Std. Desviation \\
\hline Total & 40 & 1.57 & 8.14 & 5.4148 & 1.57249 \\
\hline Valid n (listwise) & 40 & & & & \\
\hline
\end{tabular}

As can be seen in Figure 1, the most developed aspects were active methodologies (8.07), and mission and strategy (7.07). Also noteworthy were the dimensions of inclusion of professionals from businesses and organisations in the development and delivery of the curriculum (6.38), support from the management team (6.2), and organisational design (6.15). In contrast, the least developed areas were funding for entrepreneurship (3.1) and entrepreneurship training for faculty employees (3.95). 


\section{Means of the dimensions}

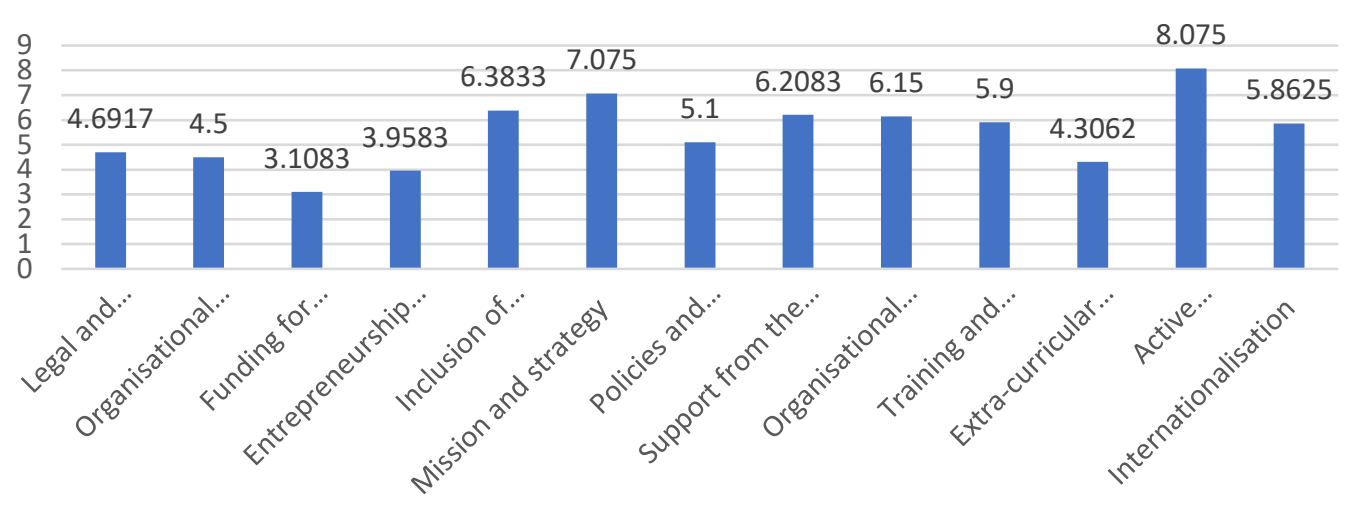

Figure 1. Means of the dimensions.

According to the perception of the participating deans, the most developed items for the development of the Entrepreneurial University were the use of active methodologies (8.87), objectives related to the development of social commitment (8.55), and the design and development of innovative educational resources (8.37). The least developed were entrepreneurship funding (1.98), policies and procedures related to the launching of spinouts (2.72), and the creation of spin-outs (2.77).

The second and third hypotheses related to whether there were significant differences by Autonomous Region, and type of faculty/school (public/private). A t-test for independent samples was performed to compare means by type of faculty/school. Levene's test for equality of variances indicated a significance level below 0.05 in dimension 12 . Therefore, it can be concluded that there were significant differences only in the 'active methodologies' dimension. This difference was greater for private universities.

An ANOVA analysis of variance was carried out to find differences by Autonomous Region, given that the populations were independent and normally distributed. Levene's statistic allowed for the hypothesis of equality of population variances to be tested. Taking into account the significance level of 0.05 , it can be concluded that there were significant differences by Autonomous Region for Dimension 6 ('mission and strategy') and Dimension 12 ('active methodologies'), with the Autonomous Regions of Navarre, Valencia and Madrid being particularly outstanding in 'active methodologies, and the Basque Country, Asturias and Navarre in mission and strategy.

The fourth hypothesis was confirmed, as the 'active methodologies' dimension obtained the highest average when considering the type of education faculty. The means for both dimensions were the highest; specifically, before the Covid-19 pandemic, the mean of the deans' perception was 8.3509, and during the pandemic it was 8.0750.

The fifth hypothesis posed was that when a university has areas of knowledge such as economics, the Entrepreneurial University is developed further. An ANOVA was performed for this analysis. Given that the p-value was greater than 0.05 , the hypothesis of equality of means was accepted. The hypothesis was rejected, and it was concluded that there were no significant differences when economics is included among the areas of knowledge of a university in terms of whether the level of development of the Entrepreneurial University would be higher or lower.

The last hypothesis, namely, that the Covid-19 pandemic has not had a significant impact on the dimensions of the Entrepreneurial University of faculties of education was confirmed, since the means were practically identical (5.5203 before Covid-19 and 5.4148 during Covid-19). However, there were significant differences in the legal and administrative context (gets worse during the pandemic), entrepreneurship training for faculty staff (gets worse during the pandemic), and inclusion of professionals from businesses/organisations in the development and delivery of the curriculum (improve during the pandemic). 
As noted in the section focused on the instrument used, each section in the questionnaire included the option of adding qualitative responses. The average participation in each of the dimensions was seven qualitative comments.

In Dimension 1, concerning the legal and administrative context, two deans stated that there was hardly any support available at their private universities. However, two other participants reported that they received internal support from public projects and from the governments of their Autonomous Regions. However, as affirmed by Participant 18 , 'it is promoted to a greater extent among students. Considering the workload that the teaching and research staff already have, adding entrepreneurship to it, for example, developing a spin-out, is overwhelming'. In Section 2, organisational context, five deans said that they were unaware of the organisational and business context close to their faculty; one of the participants considered that 'because it is a faculty that teaches education and psychology, many of these issues do not apply' (Participant 35). Only one dean provided some examples of businesses that promote entrepreneurship in their area.

In Dimension 3, entrepreneurship funding, all the respondents reported that funds to foster entrepreneurship were centralised at university level and not by faculty: 'The faculty has no direct powers on these matters' (Participant 12), 'All aspects related to capital and funds to promote entrepreneurship are actually dealt with and promoted by the University, rather than by the faculties' (Participant 6).

Regarding the training offered by the faculty to its staff for the promotion of entrepreneurial initiatives in the areas of knowledge transfer, creation of spin-outs and entrepreneurial education, five deans mentioned that these issues were managed at university level, and not at faculty level: 'Training for these issues is centralised through other university bodies' (Participant 21), 'These are initiatives that are carried out by the vice-chancellor's office and the Foundation' (Participant 25). However, two deans pointed out that this type of education was not included in the mission of their faculty, as it was in the areas of humanities and education: 'This is a faculty focused on the humanities' (Participant 31); 'because it is a faculty that teaches education and psychology, many of these issues do not apply' (Participant 35).

In the next dimension they had to provide their perception on the inclusion of experts from the business world and/or practising professionals in the development and delivery of the curriculum. Seven deans believed that guest speakers from the business world are essential and regularly delivered talks to students in Master's and more advanced years of the degrees; they gave lectures or workshops as part of different subjects, or of extracurricular programmes. In contrast, two deans were uncertain as to how practising professionals and other agents from business organisations could participate in the main university governing body, given that its structure was stipulated in the university's articles of association.

Next, in the section related to the mission and strategy of how entrepreneurship was envisaged in the faculty, three deans highlighted the importance of social commitment: 'As it is a faculty of education, social commitment is one of our principles and rules of operation' (Participant 8). One dean also held that entrepreneurship is a transversal competence in the curricula. However, three deans were reticent to accept that entrepreneurship should be part of their mission and strategy, as they believed that in a faculty where Education and Humanities are taught many of these issues did not apply.

In Section 7 they were asked to report on whether there were policies and procedures related to knowledge transfer, faculty-business collaboration and the creation of spinouts. As in previous dimensions, seven deans noted that these issues were managed at university level, the Entrepreneurship Unit and/or the vice-chancellor's office. Similarly, two deans argued that given their area of knowledge, these issues did not apply to their faculty.

The participating deans recognised the importance of entrepreneurship: 'As a dean I recognise the importance of entrepreneurship and we are working on including it as a strategic axis in the degrees, activities, etc. But nothing has been defined for the moment. We only have one transversal subject that is common to the whole university, which is 
called "Entrepreneurship" (Participant 3). However, entrepreneurship initiatives are generally operated university-wide'.

Subsequently, participants were asked to analyse the extent to which their faculty has an organisational design that facilitates entrepreneurial activity. Five deans mentioned that they did not have autonomy to seek revenues in their departments, but this does not mean that it is not common practice.

Regarding training and research in entrepreneurship, three deans reported that there had been a consolidation of entrepreneurial competences in the curriculum and in the lines of research over the past three years. According to them, some subjects related to entrepreneurship are gradually being included in the curriculum of education degrees: 'In the Early Childhood Education Degree we have a subject called "Entrepreneurship". In the Master's degree in Techno-pedagogical Design, the subject of Practical Application and Professional Initiation includes competences aimed at entrepreneurship' (Participant 3). However, students have not always welcomed these initiatives as expected: 'There has not always been the desired response from students; there is a need to work on creating a culture of entrepreneurship' (Participant 33); 'unfortunately, it is not as welcomed by students as it should be, although these events are more highly valued by Tourism Management degree students' (Participant 7).

Faculties of Education are increasingly developing extracurricular education in entrepreneurship to raise awareness among students and promote the acquisition of skills that enhance their employability. However, these initiatives are only sporadic, and 'there is still no real culture of entrepreneurship'. This should be further promoted, as 'impact is very low, and students do not seem to be interested' (Participant 3).

The use of active methodologies varied from degree to degree, although the deans generally noted that Service and Solidarity Learning, and Project-, Problem- and Challenge-Based Learning were all used. For four institutions educational innovation was a strength of their faculty and they attached importance to the use of innovative educational resources, especially after Covid-19.

Finally, the deans explained that internationalisation programmes such as Erasmus and SICUE were promoted, although participation was higher among students than among professors. In addition, joint projects were carried out with universities from other countries, especially with Portugal, Finland and Latin America.

\section{Discussion and conclusions}

It has been more than 30 years since the term Entrepreneurial University was coined [48]. However, as the results show, the level of the Entrepreneurship University in faculties and schools of education in Spain is poorly developed. There is still a long way to go for it to be fully implemented. Above all, there is a need to provide funding and grants for entrepreneurship, and to promote training in entrepreneurship for faculty staff. The training in active methodologies and the use of innovative educational resources in education faculties is remarkable and has a long track record. These results are very similar to those obtained in the study carried out by Errasti et al. [44] using the same instrument, where faculties in Spain were found to be particularly advanced in internationalisation, use of active methodologies, mission and strategy, and support from the management team. However, the legal and administrative context, funding for entrepreneurship and training of entrepreneurs were not sufficiently developed.

It can also be concluded that there are hardly any significant differences by type of faculty/school or Autonomous Region, nor when there is a faculty of economics and engineering on the same campus. It is also evident that Covid-19 has had little impact on the development of the Entrepreneurial University.

In line with Orozco, Aristizabal and Villaveces [26], some deans argued that the third mission entails more work for lecturers and professors. Thus, there is a need to strike a balance between teaching, research and entrepreneurship, and to be aware that developing the third mission does not mean replacing the traditional university missions of teaching and research [23]. It was also noted that certain dimensions of the Entrepreneurial 
University are not organised and operated at faculty level but university-wide. This is the case for funding, the promotion of entrepreneurial initiatives, and policies and procedures.

Some deans also held that entrepreneurship is alien to their faculty and not sufficiently integrated in teacher training faculties. Following Stamatović and Zlatić [49], individual and optional courses are generally offered at faculties of education, although most faculties do not provide any form of entrepreneurship education. Perhaps the university community should first understand that entrepreneurship is not simply learning how to manage a business, but also involves developing a set of transversal competences applicable to all areas of personal and working life, including creativity, leadership, innovation, teamwork and communication, among others. Although entrepreneurship had its origins in economic theory, 'the concept of entrepreneurship has evolved over time' [50] (p. 184) and not only entails educating 'for' entrepreneurship, but also educating 'through' entrepreneurship as the most effective way to inculcate the attitudes and behaviours that lead to entrepreneurial action [51]. In other words, there are two perspectives on entrepreneurship: one more linked to finance and marketing, and the other with a broader view of problem solving and the ability to take advantage of opportunities [52]. Hardiel, Highfield and Lee [52] provided evidence that entrepreneurship education provides students with the opportunity to find meaning in their learning and develop competences that would help them throughout their lives.

Currently there is an economic recession generated by the Covid-19 crisis. In this context, entrepreneurs are needed to generate income and become agents of social change [51]. According to the Spanish Entrepreneurship Observatory [53], recovery will demand more entrepreneurs with organisational and innovative skills, as well as new synergies between the entrepreneurial, corporate and academic ecosystems, promoting more spinins and spin-outs. Consequently, 'in the Entrepreneurial Universities model, greater involvement in the role of policy proponents is needed, and their participation as co-promoters in strategic regional projects' [53] (p. 50).

According to GHK [54], there is a need to foster an organisational ecosystem and an entrepreneurial culture in universities. Moreover, future teachers cannot encourage entrepreneurial attitudes among their students if they do not believe in them and if they are not convinced of their benefits. As held by GHK [54], there are no examples of good entrepreneurship practice in Spanish faculties of education. In Finland, for example, all teacher training institutions have implemented entrepreneurship education in their education programmes. These authors argued that there are four ways of implementing entrepreneurship education in initial teacher training: through compulsory modules, through optional modules, via extracurricular activities, and by creating an entrepreneurial culture. For this reason, it is suggested to implement curricular and extracurricular courses on non-business entrepreneurship, rethink the initial training of university professors, develop active methodologies and give greater autonomy to the Research and Teaching staff, among others.

The importance of entrepreneurial competences for future teachers is such that it has been included in the White Paper on the Teacher Training Degree [55]. Law 14/2013, of 27 September, on support for entrepreneurs and their internationalisation [56], stressed the need to promote the culture of entrepreneurship in university education. It also highlighted that teaching staff must have the necessary competences and skills in both initial and lifelong training. As far as university education is concerned, entrepreneurial initiatives and the setting up of business projects should be promoted.

The limitations of this study lie in the limited sample, for two main reasons. Firstly, because of the work overload caused by Covid-19 in deans' offices, and secondly, due to the change of deans during the academic year which made it difficult to have direct contact with them. Although the results cannot be extrapolated to all the faculties of education in Spain, due to the heterogeneity of the sample, they provide a preliminary approach to the current situation of Spanish faculties of education regarding entrepreneurship. 
Some suggested lines of research for the future could involve finding out the perspective of students and teaching staff on the Entrepreneurial University, and the collection of variables in relation to the fourth and fifth helix of universities, namely, the user of innovation and the environment.

Author Contributions: Conceptualization, J.P. and L.M.; methodology, J.P., MJ.B. and L.M..; software, J.P..; validation, J.P and L.M.; formal analysis, J.P..; investigation, J.P., L.M. and MJ.B.; writing-original draft preparation, J.P., MJ.B. and L.M..; writing - review and editing, J.P., MJ.B. and L.M.; visualization, J.P. All authors have read and agreed to the published version of the manuscript.

Funding: This research received no external funding.

Conflicts of Interest: The authors declare no conflict of interest.

\section{References}

1. Bacigalupo, M.; Kampylis, P.; Punie, Y.; Van den Brande, G. EntreComp: The Entrepreneurship Competence Framework. Publication Office of the European Union. 2016. https://doi.org/10.2791/593884

2. Torrejón, A. La aplicación social de la investigación: hacia una universidad emprendedora. Encuentros multidisciplinares. 2013, 15, 36-46.

3. Fernández, I.; Castro, E.; Conesa, F.; Gutiérrez, A. Las relaciones universidad-empresa: entre la transferencia de resultados y el aprendizaje regional. Revista Espacios. 2000, 21, 1-18.

4. Guerrero, M.; Urbano, D. The development of an entrepreneurial university. Journal of Technology Transfer. 2012, 37, 43-74. https://doi.org/10.1007/s10961-010-9171-x

5. Kirby, D.A. Creating entrepreneurial universities in the UK: Applying entrepreneurship theory to practice. Journal of Technology Transfer. 2005, 31, 599-603.

6. Etzkowitz et al. Pathways to the entrepreneurial university: towards a global convergence. Science and Public Policy. 2008, 35, 681-695. https://doi.org/10.3152/030234208X389701

7. Sam, C.; van der Sijde, P. Understanding the concept of the entrepreneurial university from the perspective of higher education models. High Educ. 2014, 68, 891-908. https://doi.org/10.1007/S10734-014-9750-0

8. Feola, R.; Parente, R.; Cucino, V. The Entrepreneurial University: How to Develop the Entrepreneurial Orientation of Academia. Journal of the Knowledge Economy. 2020. https://doi.org/10.1007/s13132-020-00675-9

9. Corti, E.; Riviezzo, A. Hacia la universidad emprendedora. Un análisis del compromiso de las universidades italianas con el desarrollo económico y social. Economía industrial. 2008, 368, 113-124.

10. Röpke, J. The Entrepreneurial University. Innovation, academic knowledge creation and regional development in a globalized economy. Political Science, Business. 1998.

11. Bischoff, K.; Volkmann, C.; Audretsch, D. Stakeholder collaboration in entrepreneurship education: an analysis of the entrepreneurial ecosystems of European higher educational institutions. The Journal of Technology Transfer. 2018, 43, 20-46. https://doi.org/10.1007/s10961-017-9581-0

12. Cerver, E.; Ferreira, J.; Fernandes, C. The multiple faces of the entrepreneurial university: a review of the prevailing theoretical approaches. The Journal of Technology Transfer. 2021, 46, 1173-1195. https://doi.org/10.1007/s10961-020-09815-4

13. Julià et al. El emprendimiento en el sistema universitario: el caso de las universidades de la ciudad de Valencia; Editorial de la Universidad de Cantabria: Santander, 2015.

14. Brătucu, G.; Constantin, R.; Petrisor, C.; Simona, A.; Bianca, I.; Trifan, A. Entrepreneurial University: Catalyst for Regional Sustainable Development. Sustainability. 2020, 12, 4151. https://doi.org/10.3390/su12104151

15. Pinheiro, R.; Stensaker, B. Designing the Entrepreneurial University: The Interpretation of a Global Idea. Public Organiz Rev. 2014, 14, 497-516. https://doi.org/10.1007/s11115-013-0241-z

16. Salati, G.H.; Brandão, B.; Leite, M.; Rücker, P. University Ecosystems and the Commitment of Faculty Members to Support Entrepreneurial Activity. Brazilian Administration Review. 2020, 17, 1-26. http://dx.doi.org/10.1590/1807-7692bar2020190013

17. Martínez, M.R.; García, F.; Duarte, M. Influence of the university environment in the entrepreneurial intention in public and private universities. RAUSP Management Journal. 2018, 53, 122-133. https://doi.org/10.1016/j.rauspm.2017.12.009

18. Castillo-Vergara, M. La teoría de las N-hélices en los tiempos de hoy. Journal of Technology Management E Innovation. 2020, 15, 3-5. http://dx.doi.org/10.4067/S0718-27242020000300003

19. García-Aracil, A.; Castro-Martínez, E.; Jiménez-Sáez, F.; Arroyo-Vázquez, M. What might an entrepreneurial university constitute?. Proceedings of the 2013 EU-SPRI Forum Conference, Madrid, Spain, 10/04/2013-12/04/2013.

20. Etzkowitz, H.; Zhou, C. Introduction to special issue Building the entrepreneurial university: a global perspective. Science and Public Policy. 2008, 35, 627-635. https://doi.org/10.3152/030234208X363178

21. Byrd, K.; Schmidt, J. Creating Interdisciplinary Faculty Connections Through Community as a Precursor to Enhancing Innovation, Creativity and Entrepreneurship on University Campuses. Journal of Higher Education Theory and Practice. 2019, 19, 103-111. https://doi.org/10.33423/jhetp.v19i7.2535 
22. Contreras, J.D. Emprendimiento y educación: las dos caras de la misma moneda. Available online: https://repository.uniminuto.edu/bitstream/handle/10656/5702/TAE_ContrerasHiguitaJuanDiego 2010.pdf?sequence=1\&isAllowed=y (accessed on 17 April 2021).

23. Herruzo-Gómez, E.; Hernández-Sánchez, B.; Cardella, G.M.; Sánchez-García, J.C. Emprendimiento e Innovación: Oportunidades para todos; DYKINSON, S.L.: Madrid, 2019.

24. Suska, M. Entrepreneurial studies in higher education: some insights for Entrepreneurship education in Europe. Horyzonty Polityki. 2018, 9, 143-156.

25. Heinnovate. The entrepreneurial and innovative higher education institution a review of the concept and its relevance today. Available online: https://heinnovate.eu/sites/default/files/heinnovate concept note.pdf (accessed on 14 July 2021).

26. Orozco, L.A.; Aristizabal, J.P.; Villaveces, J.L. Management Challenge in the Entrepreneurial University and Academic Performance. Open and Equal Access for Learning in School Management. 2018. https://doi.org/10.5772/intechopen.71754

27. Hannon, P. Enterprise for all? The fragility of enterprise provision across England's HEIs. Journal of Small Business and Enterprise Development. 2007, 14, 183-210. https://doi.org/10.1108/14626000710746646

28. European Commission (2008). La iniciativa emprendedora en la enseñanza superior, especialmente en estudios no empresariales. Available online: http://www.cdiex.org/aprendizaje/documento 8.pdf (accessed on 12 June 2021).

29. Wibowo, A.; Saptono, A.; Suparno. Does Teachers' Creativity Impact on Vocational Students' Entrepreneurial Intention? Journal of Entrepreneurship Education. 2018, 21, 1-12.

30. European Commission. Plan de acción sobre emprendimiento 2020. Relanzar el espíritu emprendedor en Europa. Available online: https://eur-lex.europa.eu/LexUriServ/LexUriServ.do?uri=COM:2012:0795:FIN:es:PDF (accessed on 24 May 2021).

31. Coduras, A.; Levie, J.; Kelley D.J.; Sæmundsson, R.J.; Schøtt, T. Global Entrepreneurship Monitor Special Report: A Global Perspective on Entrepreneurship Education and Training; Global Entrepreneurship Research Association, 2010.

32. European Commission. A Guiding Framework for Entrepreneurial Universities. Available online: https://www.oecd.org/site/cfecpr/EC-OECD\%20Entrepreneurial\%20Universities\%20Framework.pdf (accessed on 21 May 2021).

33. Marzocchi, C.; Kitagawa, F.; Sánchez-Barrioluengo, M. Evolving missions and university entrepreneurship: academic spin-offs and graduate start-ups in the entrepreneurial society. Journal of Technology Transfer. 2019, 44, 167-188. https://doi.org/10.1007/s10961-017-9619-3

34. European Commission. Educación en emprendimiento. Guía del educador. Available on: https://pagina.jccm.es/europa/pdf/PUBLICACIONES/2014\%20Guia\%20del\%20Educador\%20en\%20emprendimiento.pdf (accessed on 23 August 2021).

35. Council of the European Union. Conclusiones de 12 de mayo de 2009 sobre un marco estratégico para la cooperación europea en el ámbito de la educación y la formación para 2020 (2009/C 119/02). Diario Oficial de la Unión Europea 119/2 de 28/05/2009. Available on: https://eur-lex.europa.eu/legal-content/ES/TXT/PDF/?uri=CELEX:52009XG0528(01)\&from=ES (accessed on 27 May 2021).

36. Spanish Government. Estrategia España Nación Emprendedora. Available online: https://www.lamoncloa.gob.es/presidente/actividades/Documents/2021/110221-Estrategia_Espana_Nacion_Emprendedora.pdf (accessed on 12 August 2021).

37. Paños-Castro, J. Educación emprendedora y metodologías activas para su fomento. Revista Electrónica Interuniversitaria de Formación del Profesorado. 2017, 20, 33-48. https://doi.org/10.6018/reifop.20.3.272221

38. Kawamorita, H.; Salamzadeh, A.; Demiryürek, K.; Ghajarzadeh, M. Entrepreneurial Universities in Times of Crisis: Case of COVID-19 Pandemic. Journal of Entrepreneurship, Business and Economics. 2020, 8, 77-88.

39. Ratten, V. Coronavirus (Covid-19) and the entrepreneurship education community. Journal of Enterprising Communities: People and Places in the Global Economy. 2020, 14, 753-764. https://doi.org/10.1108/JEC-06-2020-012

40. Spanish Entrepreneurship Observatory. Situation of entrepreneurship in Spain due to the COVID-19 crisis Analysis and recommendations. Available online: https://www.gem-spain.com/wp-content/uploads/2020/06/GEM-COVID19-English.pdf (accessed on 27 August 2021).

41. Poh-Kam, W.; Yuen-Ping, H.; Annette, S. Towards an “Entrepreneurial University” Model to Support Knowledge-Based Economic Development: The Case of the National University of Singapore. World Development. 2007, 35, 941-958. https://doi.org/10.1016/j.worlddev.2006.05.007

42. The LISTO Project. LISTO Toolkit for Entrepreneurial Universities the concept of entrepreneurial university has emerged as a trending topic. Available online: https://listoproject.eu/wp-content/uploads/2020/12/LISTO Toolkit EntrepreneurialUniversities English.pdf (accessed on 20 June 2021).

43. Markuerkiaga, L.; Igartua, J.I.; Errasti, N. An empirical-institutional analysis of factors affecting the entrepreneurial university. Doctoral Thesis, Mondragon University, Spain, 18/12/2014.

44. Errasti, N.; Bezanilla, M.J.; García-Olalla, A.; Auzmendi, E.; Paños, J. Factors and maturity level of entrepreneurial universities in Spain. International Journal of Innovation Science. 2018, 10, 71-91. https://doi.org/10.1108/IJIS-05-2017-0043

45. Landis, J.R.; Koch, G.G. The measurement of observer agreement for categorical data. Biometrics. 1977, 33, $159-174$. https://doi.org/10.2307/2529310

46. Head of State. Organic Law 15/1999, of December 13, on Personal Data Protection. Available online: https://www.boe.es/buscar/pdf/1999/BOE-A-1999-23750-consolidado.pdf (accessed on 6 September 2021).

47. Ministry of Education. Registro de Universidades, Centros y Títulos (RUCT). Available online: https://www.educacion.gob.es/ruct/home (accessed on 17 July 2021).

48. Etzkowitz, H. Entrepreneurial scientists and entrepreneurial universities in American academic science. Minerva. 1983, 21, 198233. https://doi.org/10.1007/bf01097964 
49. Stamatović, J.; Zlatić, L. Entrepreneurship and the education of future teachers. Journal of elementary education. 2021, 14, 13-30. https://doi.org/10.18690/rei.14.1.13-30.2021

50. Borja, A.; Carvajal, H.; Vite, H. Modelo de emprendimiento y análisis de los factores determinantes para su sostenibilidad. Revista Espacios. 2020, 41, 183-196.

51. Gibb, A. In pursuit of a new 'enterprise' and 'entrepreneurship' paradigm for learning: creative destruction, new values, new ways of doing things and new combinations of knowledge. International Journal of Management Reviews. 2002, 4, $233-269$. https://doi.org/10.1111/1468-2370.00086

52. Hardiel, B.; Highfield, C.; Lee, K. Entrepreneurship education today for students' unknown futures. Journal of Pedagogical. 2020, 4, 401-417. http://dx.doi.org/10.33902/JPR.2020063022

53. Spanish Entrepreneurship Observatory. Situación del emprendimiento en España ante la crisis del COVID-19. Análisis y recomendaciones. Asociación Observatorio del Emprendimiento de España: Santander, 2020.

54. GHK. Mapping of teachers' preparation for entrepreneurship education Final Report. Available online: https://www.ab.gov.tr/files/ardb/evt/1 avrupa birligi/1 9 politikalar/1 94 egitim_politikasi/mapping en.pdf (accessed on 3 August 2021).

55. ANECA. Libro Blanco del Título de Grado en Magisterio. Available online: http://www.aneca.es/media/150404/libroblanco jun05 magisterio1.pdf (accessed on 15 June 2021).

56. Spanish Official Journal. Law 14/2013, of 27 September, on support for entrepreneurs and their internationalisation. Available online: https://www.boe.es/buscar/pdf/2013/BOE-A-2013-10074-consolidado.pdf (accessed on 2 July 2021). 